\title{
The condition of female laundry workers in Ireland 1922-1996: A case of labour camps on trial
}

\section{Eva Urban}

\section{(2) OpenEdition}

\section{Journals}

Electronic version

URL: https://journals.openedition.org/etudesirlandaises/3143

DOI: 10.4000/etudesirlandaises.3143

ISSN: 2259-8863

\section{Publisher}

Presses universitaires de Caen

Printed version

Date of publication: 30 October 2012

Number of pages: $49-64$

ISBN: 978-7535-2158-2

ISSN: 0183-973X

\section{Electronic reference}

Eva Urban, "The condition of female laundry workers in Ireland 1922-1996: A case of labour camps on trial", Études irlandaises [Online], 37-2 | 2012, Online since 30 October 2014, connection on 28 July 2022. URL: http://journals.openedition.org/etudesirlandaises/3143 ; DOI: https://doi.org/10.4000/ etudesirlandaises.3143

This text was automatically generated on 28 July 2022

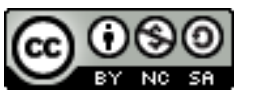

Creative Commons - Attribution-NonCommercial-ShareAlike 4.0 International - CC BY-NC-SA 4.0 https://creativecommons.org/licenses/by-nc-sa/4.0/ 


\title{
The condition of female laundry workers in Ireland 1922-1996: A case of labour camps on trial
}

\author{
Eva Urban
}

1 This article examines the class dimension of the unresolved issue of the unlawful detention of women as unpaid workers in Ireland's Magdalene Laundries between 1922 and $1996^{1}$. It applies a Marxist-feminist critique of the relationship between late capitalism and current postfeminist concepts. The analysis highlights the social and political failure of Irish society and the Irish government to engage fully with their historical responsibility for unlawful labour camps operating in the state within this time period, and focuses on the breaches of human rights effected by the very existence of these institutions. It argues that these labour camps ${ }^{2}$ systematically exploited vulnerable lower-class women, a class not accommodated by bourgeois individualist post-feminism.

In the introduction to Interrogating Post-feminism: Gender and the Politics of Popular Culture (2007) Tasker and Negra critically interrogate the concept of post-feminism, situating it "alongside other 'posts', including postmodernism and post-civil-rights discourse". They conclude that "all three posts involve an implicit understanding of history and historical change ${ }^{3 "}$ ". With regard to post-feminism this implied historical finality risks silencing the need for ongoing feminist discourse that critically engages with the unresolved nature of gender issues in much the same manner as postmodernism tends to avoid a critical engagement with contemporary social issues:

Like postmodernism, post-feminism involves a particular relationship to late capitalist culture and the forms of work, leisure, and, crucially, consumption, that thrive within that culture. Indeed, much postfeminist rhetoric is of a piece with the exhortations of the 1990's "New Economy" and the displacement of democratic imperatives by free market ones identified by Thomas Frank as "market populism"4.

3 In Ireland, developments towards the replacement of an already marginal feminist discourse with postfeminist concepts risk obliterating the need for a thorough 
historical analysis of gender and class discrimination in Irish society. In 1991 Mullin applied Simone de Beauvoir's 1949 concept of the "rarity with which women espouse a political subjectivity of their own" to Ireland, where the lack of a common feminist historical consciousness had hindered the development of collective counterhegemonic empowerment of women ${ }^{5}$. Since then, gender equality in Ireland and women's rights have significantly improved. However, in 2012, the striking absence of a full engagement with the history of the Magdalene Laundries in Irish public discourse demonstrates that a common historical consciousness is still underdeveloped. One of the most pressing unresolved social issues of importance in Ireland, not only from a feminist perspective, but also from a general social justice and worker's rights perspective, remains the case of the unpaid female workers in the labour camps referred to as the Magdalene Laundries. Only under pressure from UN recommendations since June 2011 after the efforts of a small group of courageous investigative journalists, academics, human rights activists and lawyers, has this issue, unresolved since it was first exposed in the 1990's, regained significant public interest and media presence.

4 In her recent book McCarthy traces the history of Magdalene asylums from "the Magdalene convents for repentant prostitutes in Europe (approximately A.D. 1200-1699)". She significantly examines "how these institutions, influenced by the rise of the capitalist world system, were transformed (A.D. 1700-1996) into forced-labour asylums ${ }^{6 "}$. McCarthy distinguishes important differences between the functions of these institutions in the "market centres" and in the colonized (peripheral) nations. While in a "core market power" such as England, Magdalene institutions emerged as "half-way houses", refuges "financed mostly through private philanthropy", "in England's colonies, such as Ireland, they functioned as 'forced-labour' 'homes'". She offers an explanation for this divergence based on a historical analysis that highlights how, through colonization, "economic and territorial reorganization", "new divisions of labour", and redefined "social norms" led to the development of an oppressive "romanticized" Catholic counter-culture which "further limited women's rights". A new Catholic bourgeois Irish class began to prosper in the land wars of 1879-82 when "internal class divisions developed between this new dominant group and the class of the land-less and property-less labourers"'. This structure formed the basis for the new Catholic bourgeois hegemony of post-independence Ireland.

The political revolution, when it arrived, brought with it no major social transformation; instead it set the seal on an established social order of a profoundly conservative kind. By the end of the 1920's revolutionary nationalism was not only remote from social radicalism, but actively repressing $\mathrm{it}^{10}$.

In the twentieth century the Catholic Church in Ireland transformed the original women's refuges and temporary workhouses, which since the nineteenth century had emphasized rehabilitation of women into society, into more permanent and systematic labour camps. Such institutions were now mostly run by the Catholic Church in Ireland, and after independence, supported by the Irish state.

6 Smith provides a detailed historical account of how, since 1922, the policies of the Magdalene institutions were implemented in post-colonial Ireland through the Irish government. He shows through careful analysis of the limited accessible records how the new Irish state was "an active agent and willing partner in these church-run institutions", to which "generations of Irish women were abandoned", and in which the inmates were exploited as "unpaid workers in commercial laundries", with regular 
"lifelong detention" in practice still implemented as late as the $1990{ }^{\prime} \mathrm{s}^{11}$. Smith demonstrates how the report of the Irish Free State's Commission on the Relief of the Sick and Destitute Poor, Including the Insane Report (1925-1926) formally suggested the implementations of this institutional system subsidized by the state ${ }^{12}$. These institutions departed more and more from the nineteenth century Magdalene institutions' social ethos of rehabilitation of destitute women towards permanent incarceration of a rather mixed group of women. Once committed to one of these institutions, the state abdicated all responsibility for the women and girls to the religious orders, and there is no evidence that any inspections were carried out to ensure the proper treatment of the inmates in these institutions.

7 Many of the women detained in the Magdalene Laundries were completely innocent of any transgression beyond the accident of single motherhood. Some women were imprisoned in the Magdalene Laundries for any number of reasons, including prostitution, minor crime, or simply for having had the misfortune of having been orphaned as a child, (or indeed, for having been forcibly taken away from their parents who had been deemed unfit for guardianship), being transferred from an orphanage or industrial school ${ }^{13}$ directly to a laundry upon reaching adulthood. Underage girls were sent to the laundries after having been raped, some by their own family members. Some women and girls were detained in these institutions because they suffered from disabilities, some from perceived psychological problems, some to protect the male community from their "tempting" beauty, and some for any other intolerable signs of "otherness" 14 . Once in the laundries, they were deprived of any form of physical and psychological liberty, access to the outside world, and capacity to exercise their civil rights. They were assigned new names and deprived of their individual identities. Mary Raftery describes the case of Mary Norris:

A teenage servant in Kerry, she took a forbidden night off, and was taken away to a convent where the nuns had her examined to see was she still a virgin (which she was). From there she was dispatched to the Magdalene laundry in Cork. [...] The nuns changed her name - standard practice in all the Magdalene laundries. [...] "My dignity, who I was, my name, everything was taken. I was a nonentity, nothing, nobody". The only way out was if a family member claimed you [...] She had an aunt who [...] got her out after two years of hard, unpaid labour ${ }^{15}$.

8 Inmates were forced to work for at least ten hours a day, six days a week, without pay under very difficult conditions in the unhealthy humidity of the laundries. Many former victims of these institutions have given detailed accounts of their harrowing treatment in the hands of nuns and priests ${ }^{16}$, including physical and psychological abuse and violation, the prevention of any form of meaningful human interchange or conversation with other inmates, and the deprivation of any contact whatsover with their children ${ }^{17}$, who, in many cases, were literally sold off for adoption against the will of their mothers ${ }^{18}$, or incarcerated themselves from birth in industrial schools.

Scholarship and historical analysis of the issue are severely limited by a systemic prevention of access to the archives of these institutions and governmental records. Publication on matters of institutional abuse in Ireland has also been hindered by forms of censorship: As Pine outlines in relation to child abuse in orphanages Arnold and Laskey "submitted their book to over fifteen publishers before they were able to publish their history of the orphanages run by the Poor Clares, and even then it was only published with significant changes, specifically with the 'political' material taken out $^{19}$ ". This in part explains the lack of relevant critical sources. As Smith and Pine have 
explored in two of the rare pioneering studies on Magdalene asylums and institutional abuse $^{20}$ in the absence of official historical examinations and criminal investigations, cultural representations form the basis of contemporary public memory. While both Smith and Pine show the important role of this form of cultural memory in revealing social injustice, they draw attention to the crucial need for official inquiries and procedures and for an objective historical assessment. Cultural representations have done much to bring this issue to the light of public attention, but it has not yet been elevated to the level of appropriate political and criminal proceedings. Already in 1964 Mairéad Ní Grada's critically acclaimed Brechtian Irish-language play An Triail (The Trial), which opened at the Abbey Theatre during the Dublin Theatre Festival, exposed the culpability of many sections of Irish society in the suffering and exploitation of abandoned young mothers in commercial laundries ${ }^{21}$. Since then there have been many cultural representations, the most well-known, perhaps, being the 2002 film The Magdalene Sisters by Peter Mullan. The recent site-specific theatre production Laundry by Louise Lowe, staged at the former Gloucester Street Magdalene Laundry in Dublin during the 2011 Theatre Festival received significant media attention.

However, as in the case of children incarcerated and abused in industrial schools, the women incarcerated in the Magdalene laundries are to this day deprived of their legal status and legal rights. Pine critiques the failure of the Ryan Report, published by the Commission to Inquire into Child Abuse in 2009, to fully disclose the history of institutional abuse in Ireland: a "failure not simply to detect and intervene, but to officially remember ${ }^{22 "}$ ".

This kind of partial memory on behalf of the government, is further confirmed when we consider that The Magdalene Laundries were not even included in the list of institutions to be investigated by the Commission or to be compensated by the Residential Institutions Redress Board, on the basis that they were independent from the court system and therefore private institutions, despite the fact, as was revealed in 2009, that women were sent to Laundries by state agencies and they were in receipt of state funding ${ }^{23}$.

11 In most contemporary discussions of this case of systemic exploitation of forced unpaid labour, emphasis is placed on the government's alliance with conservative Catholic Church policy, which determined certain views of the female sex. This influence enforced the treatment of women in the Republic of Ireland as second-class citizens. It could be argued that this discrimination exhibits similarities to the marginalisation of Catholics in Northern Ireland. While Catholics in Northern Ireland were mostly indirectly discriminated against in public life, married women in the Republic of Ireland were constitutionally prohibited from taking up professional careers ${ }^{24}$. The discrimination against the Catholic community in Northern Ireland has been formally addressed and corrected as part of the Peace Process. The deaths of the innocent victims of Bloody Sunday caused by British soldiers have been investigated, and the injustice done to them recognized by the British government. The unlawful detention and torture of political prisoners in Northern Ireland has also been investigated. No such official legal inquiries have been carried out on behalf of the innocent women detained for life in labour camps in Ireland between 1922 and 1996. Many of these women were detained for the extreme opposite of any form of violence, political or non-political; they were imprisoned and punished for giving the gift of life.

In the light of this discrepancy, serious questions must be asked about the ideological reasons and the power relations that prevent the proper defense of the human rights of 
a disproportionately larger number of vulnerable marginalised women victims. With the numbers of professional women in prominent posts in public life in recent years in Ireland it appears astonishing that this is so. However, as Tasker and Negra explain, "Postfeminist culture's centralization of an affluent elite [...] tends to confuse selfinterest with individuality" and "elevates consumption as a strategy for healing those dissatisfactions that might alternatively be understood in terms of social ills and discontents ${ }^{25}$ ". This effectively prevents the social solidarity of women across cultural, ethnic, race, class and hierarchical barriers.

Post-feminism is white and middleclass by default, anchored in consumption as a strategy (and leisure as a site) for the production of the self. It is thus also a strategy by which other kinds of social difference are glossed over ${ }^{26}$.

13 A close analysis leads to the conclusion that an unresolved gender issue masks an underlying class issue. What the mélange of women and girls detained in these institutions in often very different circumstances and age groups did have in common was economic dependance, poverty and social exclusion. They represented a marginalised group of people in the Republic that did not have access to financial means or decision-making processes. In contrast to other victims of domination, they lacked the sustenance of a powerful underground organisation representing their plight.

These women were deprived of the universal rights of humanity as defined in the international declaration of human rights, and from exercising the rights of equal citizenship of a democracy. These rights are still not respected: adult women who were imprisoned in the Magdalene labour camps are to this day patronised and infantilised by a whole discourse that fails to distinguish the nature of their plight from that of children who suffered abuse in industrial schools. Even in most media commentaries the focus remains on torture and abuse committed against innocent women and girls in these institutions, but the underlying issue of their unlawful detention is often ignored. Whereas children who suffered unlawfully from abuse in industrial schools were under the official guardianship of parents, church or state authorities, and therefore arguably, at least according to formal requirements, lawfully committed in the first place, the case of adult women is different. An innocent person could not have been lawfully committed, nor retained, after attaining the legal age, in any of these institutions without breaching both the Irish constitution and international human rights law. There was never a legal basis for imprisoning unmarried adult mothers, and for forcing them, under torturous conditions, to work ten hours a day without pay. It was unlawful to forcibly commit women to labour camps for unspecified periods of time, who were never given an official sentence nor release date. As Maeve O'Rourke has explained "this is not a question of applying today's standards to the past; it was illegal at the time ${ }^{27 "}$. Laundry businesses could not have lawfully gained profits by exploiting unpaid workers. Stealing and selling the babies of detained women for adoption was a major crime.

McCarthy offers a detailed historical analysis of how a succession of poor laws implemented in England and Ireland from the seventeenth to the nineteenth century paved the way for an institutional culture of workhouses exempt from regulated labour laws and inspections in Ireland. She shows evidence of how, in the twentieth century in Ireland, unregulated commercial laundries, operated by Catholic religious orders, impacted negatively on other regular businesses which had to pay their workers and comply with employment laws regarding working hours ${ }^{28}$. In 2011 more evidence of the commercial nature of these laundries emerged: 
In the early 1940s, for example, it appeared that some State bodies, most particularly the Army, were transferring their laundry contracts from commercial laundries to what were euphemistically called "institutional laundries". [...] According to Mary Jones's history of the Irish Women Workers' Union, These Obstreperous Lassies, at least one laundry was forced to close in 1941 with the loss of 25 jobs. It had just lost an Army contract to the Sisters of Charity Magdalene laundry in Donnybrook. ${ }^{29}$ laundry in Dublin's Drumcondra reveals that its regular customers included Áras an Uachtaráin, Government departments, Guinness, some of Dublin's leading hotels and Golf Clubs, Clerys, the Gaiety Theatre and Dr Steevens hospital in the city ${ }^{30 "}$.

attention that there is an urgent need to investigate the significant role of financial profits made from the hard labour of unpaid women, 30,000 in number, over a sustained period of 74 years since the inauguration of the Irish Free State. The Magdalene Laundries must be officially named for what they were: illegal labour camps. When faced with 74 years of exploitative slave labour camps operating in Ireland, the fact that torture and abuse were methods employed in these camps to render and hold the victims in an obedient state is only part of the issue, as such techniques are common to all labour camps throughout history. The establishment of such camps is unlawful whether or not such methods are employed.

The ILO (International Labour Organisation) defines forced labour as work or service exacted from a person under threat or penalty, which includes penal sanctions and the loss of rights and privileges, where the person has not offered him/herself voluntarily (ILO 2001a) ${ }^{31}$.

The emerging evidence that "women who escaped were caught by the police and returned to the punitive and often brutal regime within the laundries ${ }^{32}$ " uncannily resembles the operation of other such camps in history by State forces in collusion with ordinary citizens. According to Raftery "generations of Irish people colluded in this, using the laundries when it suited them to clean their clothes and control their

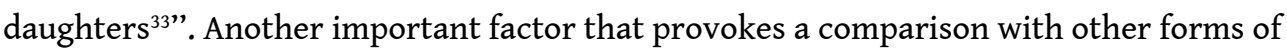
labour camps is evidence that "approximately 25 percent" of the children in industrial schools were the children of inmates of these camps, and many of the little girls were systematically groomed for life as a labouring slave in a Magdalene laundry, in which they were placed, often before their childhood was over ${ }^{34}$.

The Industrial Schools were "a crucial element in maintaining social control of the population", a way of training servants and farm labourers for the Catholic middle classes and a method to "entrench and perpetuate a rigid class system in Ireland ${ }^{35}$ ".

The 1993 discovery of 155 bodies buried in a mass grave under the building of High Park, run by the Sisters of Our Lady of Charity of Refuge, the largest Magdalene Laundry in Ireland, chillingly suggests the possibility of even further points of comparison with other forms of labour camps. Raftery explains when a company the religious order "had invested in went bust, they decided to sell off a portion of their Dublin land holdings to cover the losses. [...] the land contained a mass grave" and it subsequently emerged that "there were 22 more bodies in the grave than the nuns had listed when applying for permission to exhume. Over one-third of the deaths had never been certified. The nuns did not even appear to know the names of several of the women ${ }^{36 "}$. Death certificates are a legal requirement in Ireland. 

bodies were hurriedly burned and anonymously interred in a mass grave in Glasnevin cemetery in Dublin, before any investigation into the cause of the deaths of these women could be carried out, or even their identities established. The sinister implications of this particular (State) action are striking. Also striking is the fact that despite repeated media exposure of this incident, no investigation has been carried out yet. General public reaction to this also appears somewhat low-key, considering the reactions other such unaccounted for and covered-up deaths would provoke within international contexts. The severe violation of human rights is evident in the denial of the individual identities of these female victims both in life (when their names were systematically taken away from them to make them untraceable) and in death, (when they were cremated anonymously).

21 Adult women are represented, even by many of those advocating their plight, as if they were unfortunate child victims (of which there were also many) of the abuse of their adult guardians. These "guardians", the Catholic Church and the State, are called to account for abuse committed against those under their "guardianship". Criticism is often limited to that of institutional abuse, when the obvious main issue in relation to the Magdalene Laundries is that of unlawful detainment, internment without trial, and forced labour of adult women, whose constitutional rights of independent decision were brutally violated. The relative disregard for this unlawful incapacitation and incarceration of adults in public discourse amounts to a replication of the violation of these women's rights. Once more, these women are deprived of the right of agency, and subjugated to bourgeois-patriarchal domination. According to Rancière's analysis the bourgeois class continues to reinforce inequality, domination and the servitude of the labouring classes as a natural condition of humanity, even when championing equality and the critique of domination in theory:

En disant que les hommes étaient libres et égaux en droit, elle (la classe bourgeoise libérale) n'a jamais manqué d'ajouter qu'il n'en était pas de même en fait, qu'il était dans la nature des choses que les hommes fussent inégaux, que le couple de la domination et de la servitude était inscrit dans la nature de l'homme ${ }^{37}$.

According to Marxist feminism, gender discrimination and class discrimination are interconnected, as, "in capitalist social formations, the nuclear family emerges as the dominant but not exclusive context in which social classes are produced ${ }^{38}$. In The Origin of the Family: Private Property and the State Engels has offered a detailed sociohistorical analysis of the development of the capitalist interconnection between private property and the institution of the patriarchal family. He describes the formation of the family as an economic unit within the capitalist system as the origin of gender inequality. According to Engels "the distinction of rich and poor appears beside that of freemen and slaves - with the new division of labour, a new cleavage of society into classes $^{39}$ ".

The separation of the family from the clan and the institution of monogamous marriage were the social expressions of developing private property; so called monogamy afforded the means through which property could be individually inherited. And private property for some meant no property for others, or the emerging of differing relations to production on the part of differing social groups $^{40}$.

Études irlandaises, 37-2 | 2012 
In late nineteenth-century Ireland, as a new bourgeois Catholic class achieved degrees of emancipation from British colonial domination, changed inheritance laws transformed rural society into one dominated by large farmers, where property previously split between all the children was now inherited only by the eldest son ${ }^{41}$. This effectively created a new landless labouring class, and enforced mass emigration. Female monogamy became more important to ensure the passing on of property through the patriarchal family line, and as there was no land for most children of a family to inherit, and efforts were made to accumulate wealth, the marriage rate of Ireland $\operatorname{sank}^{42}$. In a society with a large quantity of surplus labour power such as Ireland ${ }^{43}$, young women without independent means had little opportunity to contribute material and production value to society outside of marriage. Without a substantial dowry, not even the option of a religious vocation was open to them. Consequently, many young working-class women who did not emigrate during times of economic deprivation (young women constituted the largest number of economic emigrants) became economic burdens on their families. Any loss of respectability in the eyes of the patriarchal community threatened the economic survival of their families in small-town and rural communities. The Magdalene Laundries were not the concern of economically secure women. Magdalene Laundries were for a cross-section of poor, lower class women and girls with no prospects. They constituted a convenient dumping ground for a materialistic society's unvalued, unwanted, and defenseless pool of free labour, supplying cheap laundry services to state institutions, the business community and the middle-classes (including women) across Irish society. We can therefore define the "second-class" status of laundry workers quite literally as based on direct class discrimination as well as gender discrimination. Tasker and Negra assert the importance of a feminist critique that challenges "a limited vision of gender equality as both achieved and yet still unsatisfactory", which "underlines the class, age, and racial exclusions that define post-feminism and its characteristic assumption that the themes, pleasures, values, and lifestyles with which it is associated are somehow universally shared and, perhaps more significant, universally accessible ${ }^{44}$. The obvious class dimension and the involvement and culpability of many sections of Irish society may also in part explain why, in comparison with other forms of church abuse and State neglect, the exploitation of these women has received only limited attention (mostly in the Irish Times) from the media. Significantly, Smith draws attention to the "baffling" "absence of an Irish-produced documentary focusing on these institutions ${ }^{45}$ ". Since the publication of Smith's book in 2007, the only Irish-made documentary The Forgotten Maggies (2009) by Stephen O'Riordan has been aired at the Galway Film Festival in 2009 and on TG4 in 2011. It is indeed remarkable that sections of the Irish mainstream Media, including RTE, who finally aired Mary Raftery's documentary States of Fear about child abuse and industrial schools in 1998, have remained "unwilling to investigate what the Irish Times referred to as 'The Magdalene Scandal' (1998)' ${ }^{46}$ for a long time. As Smith puts it: "One is left to ponder what it is about the women confined to the Magdalene laundry that disqualifies them from the Irish media's penchant for exposing Church and State hypocrisy, abuse and exploitation ${ }^{47}$."

Following a submission by Global Human Rights fellow Maeve O'Rourke on behalf of the advocacy group Justice for Magdalenes, the U.N. Committee against torture issued a damning report in May 2011 on the Irish State's failure to investigate the human rights abuses committed under the umbrella of the Magdalene Laundries. 
The Committee states that it is "gravely concerned at the failure by the State party to protect girls and women who were involuntarily confined between 1922 and 1996 in the Magdalene Laundries, by failing to regulate their operations and inspect them, where it is alleged that physical, emotional abuses and other ill-treatment were committed amounting to breaches of the Convention".

The Committee recommends "that the State party should institute prompt, independent, and thorough investigations into all allegations of torture, and other cruel, inhuman or degrading treatment or punishment that were allegedly committed in the Magdalene Laundries".

It also recommends that the State "ensure that all victims obtain redress and have an enforceable right to compensation including the means for as full rehabilitation as possible".

Finally, the Committee recommends that the State "in appropriate cases, prosecute and punish the perpetrators with penalties commensurate with the gravity of the offences committed ${ }^{48}$ ".

However, since May 2011, official reactions of the Irish government to this report have been rather limited and investigations have yet to be implemented. Mary Lou McDonald's strong demand for prosecutions is a unique call for justice in Ireland in 2011. In the Dáil in June 2011 she raised "the damning criticism of the State's failure to protect women who were detained and abused in the Magdalene laundries" as "contained in the United Nations Committee Against Torture report on Ireland".

Given the scale of the failure of the State in respect of these women, what does the Taoiseach propose to do? When will the Taoiseach act on the recommendations of the UN? When will these women get the recognition, the apology and the compensation they deserve ${ }^{49}$ ?

The Taoiseach Enda Kenny's response to McDonald's challenge (and to the UN report) on this issue in the Dáil can be described as evasive and generalized at best, with no clear engagement with the specific issues raised. The severe human rights abuses incurred are euphemized as "personal difficulties", the victims are not mentioned specifically, instead, he speaks of "people involved in the Magdalene laundries", which, indeed, could refer to the incarcerated women as well as to their torturers. This is startlingly in contrast with the State's clear denunciation of Church child sexual abuse in 2011 and reflects the state's greater culpability in the Magdalene laundries. The significance and the contemporary relevance of the State's responsibility for abuses perpetrated into the 1990's is denied by presenting it like a century old issue and by the attempt to create a false historical distance. Finally, when referring to the UN report, the Taoiseach refers to praise received for progress achieved in the area of domestic violence and human trafficking in order to sideline and detract from the issue at hand:

I am sure the Deputy empathizes, as I do, in respect of the difficulties, the emotional trauma and the personal difficulties of many of the people involved in the Magdalene laundries and what they went through. The Deputy is also aware that this goes back to before the turn of the last century. [...] In its statement, the [UN] Committee acknowledged this country's commitment to engage with it in a constructive manner. The Committee commended Ireland on the detailed written replies supplied by the Irish delegation during the formal hearing examination and on the significant progress made by the authorities in recent years in areas such as the prevention of domestic violence and human trafficking ${ }^{50}$. interdepartmental committee, "to clarify any State interaction with the Magdalene Laundries and to produce a narrative detailing such interaction ${ }^{51 "}$. On 1 July $2011 \mathrm{Dr}$ Martin McAleese was appointed the Chair of the interdepartmental committee. In 
October 2011 Justice for Magdalenes submitted a "revised 'Restorative Justice \& Reparations Scheme for Magdalene Laundry Survivors' to Minister for Justice Alan Shatter and Minister for Disability, Equality and Mental Health, Kathleen Lynch ${ }^{52 "}$. On 25 October 2011 the Inter-Departmental Interim Report was published by the Department of Justice, in which the role of the committee is limited to that of a "factfinding" one. In relation to such "fact-finding" however, a serious issue arises from the requirements of the Data Protection Act: Significantly the "Committee maintains that 'all such records will be destroyed and/or returned to the relevant Religious Order upon conclusion of the Committee's work and publication of its Report' ${ }^{53}$ ". In the light of the possible destruction of irreplacable historical records Mari Steed argues that "given already existing evidence of State complicity in Magdalene placements and remand of women, it is clear that the State was an 'actor' and 'subcontracted' care responsibility to the religious orders. As such, they have a mandate to retain and protect all records and must also be deemed data controllers ${ }^{54 "}$. On 15 March 2012 statements were made by the Irish Human Rights Commission, the Women's Human Right's Alliance, and Justice for Magdalenes, "urging the government to comply with the recommendations of the UN Committee against Torture and Irish Human Rights Commission to institute a statutory inquiry and compensation scheme for the Magdalene Laundries abuse ${ }^{55}$ ". It remains to be seen what actions will be taken to address this issue. So far, the generally euphemistic and evasive language employed in official government statements does not raise confidence that this new inquiry will deal with the full scale of the grave human rights abuses that occurred. 127 recommendations were made in October 2011 for Ireland "to strengthen its human rights protections". On 15 March 2012 the government responded to a recommendation from Thailand to institute a statutory inquiry and compensation scheme for women and children abuse victims by explaining that "an apology has already been made to victims of childhood abuse and compensation awarded by the Residential Institutions Redress Board". Speaking to the Human Rights Council, Jacqueline Healy of WHRA said:

"We are gravely concerned that in accepting the Thai recommendation for a statutory inquiry and compensation scheme for women and children victims of abuse, there is no mention of the women survivors of Ireland's Magdalene Laundries who have been denied reparation ${ }^{56 "}$.

12 months after the UN report, "Magdalene survivors are still waiting for an apology, redress and reparation ${ }^{57}$. The case clearly needs more international attention to exercise pressure on the Irish government. The Irish government's limited response to the UN report, the previous Irish inquiries into institutional abuse, as well as much public commentary to date, fail to acknowledge the essential fact that the very existence of these institutions was unlawful. The full extent to which church, government, judiciary and society in Ireland (and indeed in other countries) were involved in the imprisonment of adult women and underage girls in unlawful labour camps, in the kidnapping of their children for commercial gain, and in failing to account for the deaths and burials of a number of women detained for life in such camps must be brought to light. Beyond the urgent need to apologise to, and to compensate the victims who are still alive, truth must be recovered, justice done, perpetrators brought to account, history recorded, and the cover-up of the past, and future repetition of such crimes prevented by an appropriate process of official remembrance. Given the involvement of the Irish government and judiciary in the abuses and the cover-up of those abuses, it may not be possible to accomplish this task unless the United Nations engages with the issue beyond a mere report of recommendations, and instigates an independent international investigation. 


\section{NOTES}

1. This article focuses on the development of such institutions in Ireland in the period since the inauguration of the Irish Free State in 1922 until the closure of the last such institution in the Irish Republic in 1996.

2. UCD Law lecturer Maeve O'Rourke has clarified that the women's detention amounted to "forced labour" under terms of a 1930 Forced Labour Convention, signed by Ireland in 1931. Maeve O'Rourke, quoted by Patsy McGarry, "Laundries used forced labor", The Irish Times, 6 July, 2011, [http://www.irishtimes.com/newspaper/ireland/ 2011/0706/1224300157438.html].

3. Yvonne Tasker and Diane Negra, Interrogating Post-feminism: Gender and the Politics of Popular

Culture, Duke University Press, 2007, p. 6.

4. Ibid.

5. Molly Mullin, "Representations of History, Irish Feminism, and the Politics of Difference", Feminist Studies, Vol. 17, No. 1 (Spring, 1991), p. 29-50.

6. Rebecca Lea McCarthy, Origins of the Magdalene Laundries: An analytical history, Jefferson, North Carolina, McFarland, 2010, p. 1.

7. McCarthy, op. cit., p. 2.

8. Ibid.

9. Terry Eagleton, Heathcliff and the Great Hunger: Studies in Irish Culture, London, Verso, 1995, p. 93.

10. Ibid., p. 96.

11. James M. Smith, Ireland's Magdalen Laundries and the Nation's Architecture of Confinement, Manchester, Manchester University Press, 2007, p. 82.

12. Ibid., p. 52-54.

13. Industrial Schools in Ireland were reformatories run by the Catholic Church on behalf of the Irish state, where orphans or neglected children were often systematically abused.

14. James Smith, op. cit., p. 15-16.

15. Mary Raftery, "Ireland's Magdalene Scandal must be layed to rest: Church, family and State were all complicit in the abuse of thousands of women", The Guardian, Wednesday, 8 June, 2011.

16. Patsy McGarry, "State must confront Magdalene Tragedy", The Irish Times, 7 June 2011, [

http://www.irishtimes.com/newspaper/opinion/2011/0607/1224298498372.html ].

17. Fintan O'Toole, "We should be recovering our Magdalene History, not burying it", The Irish Times, 20 October, 2011, [

http://www.irishtimes.com/newspaper/weekend/2011/1029/1224306677792.html ]. 
18. See Mike Milotte, Banished Babies: the Secret History of Ireland's Baby Export Business, Dublin, New Island Press, 1997.

19. Emilie Pine, The Politics of Irish Memory, Basingstoke, Palgrave Macmillan, 2010, p. 19. 20. Other early histories of such institutions are Maria Luddy, Women and Philantropy in Nineteenth Century Ireland, Cambridge, Cambridge University Press, 1995, Mary Raftery and Eoin O'Sullivan, Suffer the Little Children: The Inside Story of Ireland's Industrial Schools, Dublin, New Island Books, 1999, Frances Finnegan, Do Penance or Perish: A Study of Magdalen Asylums in Ireland, Oxford, Oxford University Press, 2004, and Mavis Arnold, Heather Laskey, Children of the Poor Clares, Appletree Press, 2004.

21. James M. Smith, op. cit., p. 83.

22. Emilie Pine, op. cit., p. 24.

23. Ibid.

24. Goretti Horgan, "Changing Women's Lives in Ireland", International Socialism Journal, Issue 91, Summer 2001, [

http://pubs.socialistreviewindex.org.uk/isj91/horgan.htm

], accessed 12 April 2012, p. 9.

25. Tasker and Negra, op. cit., p. 2.

26. Ibid.

27. Maeve O'Rourke, quoted by Patsy McGarry, "Laundries used forced labor", The Irish Times, 6 July, 2011, [

http://www.irishtimes.com/newspaper/ireland/2011/0706/1224300157438.html

].

28. McCarthy, op. cit., p. 160.

29. Mary Raftery, "State apology is only way to express wrong done to Magdalenes", The Irish Times, 20 June 2011, [http://www.irishtimes.com/newspaper/opinion/ 2011/0620/1224299222411.html].

30. Patsy McGarry, "Áras an Uachtaráin among users of Magdalene laundry", The Irish Times, 22 June, 2011, [http://www.irishtimes.com/newspaper/frontpage/ 2011/0622/1224299385729.html].

31. Kanchana N. Ruwanpura, Pallavi Rai, Forced Labour: Definition, Indicators and Measurement, International Labour Office, Geneva, 2004, p. 3.

32. Mary Raftery, "Ireland's Magdalen Scandal must be layed to rest: Church, family and State were all complicit in the abuse of thousands of women", The Guardian, Wednesday, 8 June, 2011.

33. Ibid.

34. McCarthy, op. cit., p. 4.

35. Horgan, op. cit., p. 7. Mary Rafferty and Eoin O'Sullivan, Suffer the Little Children: the Inside Story of Ireland's Industrial Schools, Dublin, New Island Press, 1999, p. 26.

36. Mary Raftery, "Ireland's Magdalen Scandal must be layed to rest: Church, family and State were all complicit in the abuse of thousands of women", The Guardian, Wednesday, 8 June, 2011.

37. "While saying that all men were free and equal in their rights, the liberal bourgeois class has never failed to add that the facts don't correspond to this, that it was in the nature of things that men would be unequal, that the pairing of domination and servitude was inscribed in human nature." Jacques Rancière, La leçon d'Althusser, Paris, La Fabrique éditions, 2011, (first edition 1974), p. 162. 
38. Martha Gimenez, The Oppression of Women: A Structuralist Marxist View, in Rosemary Hennessy and Chrys Ingraham, (eds.), Materialist Feminism: A reader in class, difference and women's lives, New York, London: Routledge, 1997, p. 71-81, p. 75.

39. Friedrich Engels, The Origin of the Family: Private Property and the State, International Publishers Co., 1942, 1970, 1972, 2001, p. 223.

40. Eleanor Burke Leacock, "Introduction" to Friedrich Engels, The Origin of the Family: Private Property and the State, p. 41.

41. Current historical scholarship is divided on whether or not the Famine functioned as a "watershed" in this development. Mary Daly, Revisionism and Irish History: the Great Famine, in D. George Boyce and Alan O'Day, eds., Revisionism and the revisionist controversy, London, Routledge, 1996, p. 71-89, p. 77.

42. For a detailed analysis of these developments see Horgan, op. cit., p. 2. and JJ Lee, The Modernisation of Irish Society, 1848-1918, Dublin, Gill and Macmillan, 1973.

43. See Marx and Engels, Capital, p. 767-781.

44. Tasker and Negra, op. cit., p. 2.

45. James M. Smith, op. cit., p. 116.

46. Ibid.

47. Ibid.

48. Cara Solomon, "UN Committee Against Torture Calls on Ireland to Investigate Magdalene Laundries", International Human Rights Clinic, Human Rights Program at Harvard Law School, [

http://harvardhumanrights.wordpress.com/2011/06/06/un-committee-against-torture-calls-onireland-to-investigate-magdalene-laundries/

], accessed on $27 / 12 / 2011$.

49. Sinn Féin TD Mary Lou McDonald, Dail, quoted by Pól O Muiri, in Studies: An Irish Quarterly Review, Autumn 2011, vol.100, nº 399.

50. Dáil Debates $7^{\text {th }}$ June 2011, (quoted by Pól O Muiri). in Studies: An Irish Quarterly Review, Autumn 2011, vol. 100, $n^{\circ} 399$.

51. [

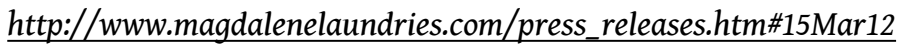

], accessed on 3 April 2012.

52. Idem.

53. "Justice for Magdalenes cautiously welcomes Magdalene Inter-Departmental Committee Interim Report”, JFM, 26 October 2011, [

http://www.magdalenelaundries.com/press_releases.htm\#15Mar12

], accessed on 3 April 2012.

54. Ibid.

55. “Irish Human Rights Commission, Women's Human Rights Alliance and Justice for Magdalenes (JFM) address UN Human Rights Council on Magdalene Laundries abuse", JFM, 15 March 2012,

[

http://www.magdalenelaundries.com/press_releases.htm\#15Mar12

], accessed on 3 April 2012. 
56. Ibid.

57. "Press Release 28 May 2012 One year after UN Recommendation Magdalene women are no closer to an apology or redress". Justice for Magdalenes. [

http://www.magdalenelaundries.com/press_releases.htm\#070612

].

\section{ABSTRACTS}

This paper examines the class dimension of the unresolved issue of the unlawful detention of women as unpaid workers in Ireland's Magdalene Laundries between 1922 and 1996 within the context of a Marxist-feminist critique of current postfeminist concepts. The analysis highlights the social and political failure of Irish society and the Irish government to engage fully with their historical responsibility for unlawful labour camps operating in the state within this time period, and focuses on the breeches of human rights effected by the very existence of these institutions. In Ireland, a particular danger is attached to replacing feminist discourse with a concept such as post-feminism that aims to render the former obsolete, because a complete historical analysis and understanding of gender issues has by no means been completed. In 2011 one of the most pressing unresolved social issues of importance in Ireland, not only from a feminist perspective, but also from a general social justice and worker's rights perspective, still remains the case of the unpaid female workers in the labour camps known as Magdalene Laundries.

Cet article analyse la question, non résolue à ce jour, de la détention illégale de femmes comme employées non rémunérées dans les Magdalen Laundries en Irlande de 1922 à 1996 sous l'angle des classes sociales, en se plaçant dans la perspective d'une critique marxiste féministe des concepts post féministes. Cette analyse met en évidence l'échec social et politique de l'État et du gouvernement irlandais à prendre leurs responsabilités dans le fonctionnement de camps de travaux forcés à cette époque et insiste sur les violations des droits de l'homme résultant de l'existence même de ces institutions. En Irlande, il existe un danger de voir des concepts comme le post-féminisme remplacer et rendre obsolète le discours féministe, dans la mesure où les questions relatives aux rapports entre les sexes n'ont pas fait l'objet d'une analyse historique approfondie. En 2011, le cas des employées non rémunérées travaillant dans les institutions de travaux forcés appelées Magdalen Laundries, reste l'une des questions sociales les plus importantes du pays, non seulement d'un point de vue féministe mais également du point de vue de la justice sociale et des droits des travailleurs. 


\section{INDEX}

Keywords: social classes, Irish State (Free State), feminism and post-feminism, women, Ireland socio-economic issues, Irish State (Republic of Ireland), human rights, justice, institutional abuse, Magdalen Laundries

Mots-clés: Magdalen Laundries, Irlande - questions économiques et sociales, État irlandais (République d'Irlande), féminisme et post-féminisme, droits humains, femmes, justice, classes sociales, maltraitance institutionnelle, État irlandais (État libre)

\section{AUTHOR}

\section{EVA URBAN}

Université de Rennes 2 